Como citar: ESTEVES, João Luiz Martins. SANTANA, Lucas Ferreira. O Instituto da Repercussão Geral no Recurso Extraordinário e o Novo Código De Processo Civil. Revista do Direito Público. Londrina, v.11, n.1, p.163-182, jan/abr.2016. DOI: $\quad 10.5433 / 1980-511 \mathrm{X}$. 2016v11n1p163. ISSN: 1980$511 X$.

* Doutor em Direito, pelo Programa de Doutorado da Pós Graduação em Ciências Jurídicas da Universidade Federal de Santa Catarina (UFSC). Mestre em Direito, Estado e Cidadania, pelo Programa de Mestrado da Universidade Gama Filho (UGF/RJ). E-mail: joao. esteves1000@gmail.com

** Especialista em Direito Empresarial pela Universidade Estadual de Londrina. E-mail: lucas_santana1@ hotmail.com

\section{O Instituto da Repercussão Geral no Recurso Extraordinário e o Novo Código De Processo Civil}

\author{
The Institute of General Repercussion the \\ EXTRAORDINARY APPEAL AND NEW CIVIL \\ Process Code \\ * João Luiz Martins Esteves \\ ** Lucas Ferreira Santana
}

Resumo: O presente trabalho consiste em um estudo sobre o Recurso Extraordinário e o requisito de admissibilidade da Repercussão Geral. Concentra-se na análise da condição de Repercussão Geral como requisito intrínseco de admissibilidade do Recurso Extraordinário. Aprecia-se a natureza jurídica do requisito recursal, bem como se compara a recente ferramenta com os parâmetros estabelecidos anteriormente pela legislação, com um breve histórico da Arguição de Relevância. Busca-se a compreensão dos elementos considerados para a configuração da Repercussão Geral na legislação infraconstitucional, especificamente nas disposições do artigo 1029 e seguintes do Novo Código de Processo Civil. Finalmente, analisa-se o procedimento de apreciação do requisito da Repercussão Geral e as principais alterações que o novo Código de Processo Civil trará ao Instituto, bem como a recente atualização da lei 13.256/ 2016.

Palavra-chave: Recurso Extraordinário. Repercussão Geral. Novo Código de Processo Civil.

Abstract: This work consists of a study on the extraordinary appeal and the admissibility requirement of General Repercussion. It focuses on analysis of the condition of General Repercussion as an intrinsic requirement of admissibility of the extraordinary appeal. It is appreciated the legal nature of the appeal requirement and compares the recent tool with the parameters previously established by law, with a brief history of the accusation of Relevance. Seeks to understand the elements considered for configuring the General Repercussion in the infraconstitutional legislation, specifically the provisions of Article 1029 et seq of the New Code of Civil Procedure. Finally, we analyze the procedure examination of the General Repercussion requirement and the main changes that the new Code of Civil Procedure will bring to the Institute and the recent update of the law $13.256 / 2016$.

Keywords: Extraordinary Appeal. General Repercussion. New Civil Procedure Code. 


\section{INTRODUÇÃO}

A condição de Repercussão Geral traduz-se em um requisito específico para a admissibilidade do Recurso Extraordinário. Tal inovação relacionou-se diretamente com a situação do STF frente ao grande número de recursos que estavam à espera de apreciação.

Destarte pretendiam uma revisão da decisão em nível de terceira ou quarta instância, do que propriamente salvaguardar uma disposição constitucional, optou-se pela determinação de um requisito que filtrasse estas demandas, admitindo apenas aquelas que continham essencialmente questões que transcendessem os interesses subjetivos da causa.

Entretanto, passada mais de uma década desde a instituição do requisito de repercussão geral, ainda é possível encontrar dissonâncias relativas ao alcance desse instituto de caráter jurídico processual e de viés constitucional.

Sendo assim, é necessário um aprofundamento do estudo por meio da análise de sua natureza jurídica, para depois verificar quais os elementos que a compõem, na tentativa de elaborar sua definição, e também sua diferenciação do instituto da arguição de relevância, para, por último, apreciar o procedimento de admissibilidade do Recurso Extraordinário a partir da sua demonstração, com as consequências de sua aceitação ou recusa.

\section{NATUREZAJURÍDICA}

Conforme exposto, a demonstração da Repercussão Geral da questão constitucional no caso concreto, exigida pelo $\S 3^{\circ}$ do art. 102 da CRFB/88, constitui requisito de admissibilidade específico para interposição do Recurso Extraordinário perante o STF.

Assim, além do preenchimento dos demais requisitos de admissibilidade, como o interesse recursal, "a legitimidade e a tempestividade, por exemplo, também a Repercussão Geral deverá ser demonstrada sob pena de não conhecimento do Recurso Extraordinário" ${ }^{1}$.

Os pressupostos de admissibilidade recursal reputam-se intrínsecos quando concernem à existência, ou não do poder de recorrer. São considerados extrínsecos, ao contrário, quando atinem ao modo de exercer esse poder. Nesta

MONTENEGRO FILHO, Misael. Curso de direito processual civil: teoria geral dos recursos, recursos em espécie e processo de execução. 4.ed. São Paulo: Atlas, 2007. p. 193. 
linha, a Repercussão Geral é requisito intrínseco de admissibilidade recursal: não havendo repercussão geral, não existe poder de recorrer ao Supremo Tribunal Federal.

A natureza jurídica da Repercussão Geral, como se pode notar, é de requisito de admissibilidade e não de recurso, pois não tem o condão de obter a reforma ou invalidação do julgado.

Da mesma forma, a Repercussão Geral não pode ser considerada como fundamento do Recurso Extraordinário, pois ela se situa no plano da admissibilidade, sendo que a sua presença não gera, somente por isso, a procedência da questão de mérito discutida no recurso extraordinário. A repercussão geral não influencia nem vincula o juízo de admissibilidade sobre os demais requisitos genéricos e específicos de admissibilidade do RE, muito menos o juízo de mérito.

Outrossim, desvinculando a Repercussão Geral dos pressupostos constitucionais de admissibilidade e enfatizando o seu caráter específico, afirma Marinoni:

Trata-se de mais um requisito de admissibilidade do recurso extraordinário, com a diferença de que não se coloca no mesmo plano daqueles requisitos elencados nas letras do inciso III do art. 102, pois o recorrente, a partir de agora, além de ter que fundamentar o extraordinário em uma dessas letras, terá que demonstrar a 'repercussão geral das questões constitucionais discutidas no caso' ${ }^{2}$.

Em suma, a Repercussão Geral tem natureza jurídica de requisito específico de admissibilidade do Recurso Extraordinário, de caráter intrínseco, não estando relacionada às hipóteses de cabimento previstas pelas alíneas "a" a "d" do inciso III do art. 102 da CRFB/88, nem com os demais requisitos de admissibilidade, antecedendo qualquer análise do mérito do RE, por isso não se constituindo no próprio recurso.

\section{CONCEITO DE REPERCUSSÃO GERAL}

Existe certa dificuldade em delimitar o conceito de Repercussão Geral, pois de acordo com Schlosser e Wickert, a CRFB/88, a Lei n. 11.418/2006 e a Emenda Regimental n. 21/2007 do STF mencionam uma definição um tanto

${ }^{2}$ MARINONI, Luiz Guilherme. Manual do processo de conhecimento. 9.ed. rev., atual. e ampl. São Paulo: Revista dos Tribunais, 2010. p. 573. 
flexível deste instituto, cuja intenção do legislador seria respeitar as mais variadas situações que possam surgir e confrontar o texto constitucional, autorizando então a apreciação do RE pelo STF.

As referidas autoras assim expõem:

A lei pode regulamentar o que realmente repercute, mas não é possível ter um significado fechado, inflexível, porque na prática ocorrem situações diversas que não podem ser previstas pelo legislador previamente. O que é possível fixar são critérios a serem utilizados, como é o caso dos valores sociais, jurídicos, econômicos e políticos ${ }^{3}$.

Neste sentido, a função do conceito vago não é outra senão a de driblar a complexidade das relações sociais do mundo contemporâneo e a de fazer com que haja certa flexibilização adaptativa na construção e aplicação da norma jurídica. Eles se constituem na resposta adequada à permanente e frequentíssima mobilidade da realidade objetiva abrangida pela previsão normativa, permitindo uma 'aplicação atualista e individualizada da norma, ajustada às peculiaridades de cada situação concreta'. Uma das mais relevantes funções do conceito vago é a de fazer com que a norma dure mais tempo, fixar flexivelmente os limites de abrangência da norma, fazê-la incidir em função das peculiaridades de casos específicos.

A Repercussão Geral também tem uma definição em sentido amplo: A repercussão geral é o requisito de admissibilidade consubstanciado na exigência de que o recorrente demonstre a relevância da questão constitucional veiculada no recurso extraordinário, sob o prisma econômico, político, social ou jurídico, a fim de ensejar o conhecimento do recurso pelo Supremo Tribunal Federal, em razão do superior interesse da preservação do direito objetivo.

Borges, genericamente, conceitua Repercussão Geral como o resultado de um "proceder que pela sua importância e extensão atinge um número razoável e indeterminado de pessoas, versando sobre questões constitucionais relevantes" 4 .

Para Gomes Júnior haverá repercussão, em determinada causa/questão, "quando os reflexos da decisão a ser prolatada não se limitarem apenas aos

\footnotetext{
3 SCHLOSSER, Lizelote Minéia. WICKERT, Lisiane Beatriz. A inserção e a regulamentação da repercussão geral como pressuposto de admissibilidade do recurso extraordinário. Revista de Processo, São Paulo, v.33, n.161, p. 122, 2008.

${ }^{4}$ BORGES, Marcos Afonso. O recurso extraordinário e a repercussão geral. Revista de Processo, São Paulo, v. 33, n. 156, fev. p. 41, 2008.
} 
litigantes, mas, também, a toda uma coletividade. Não necessariamente a toda coletividade (país), mas de uma forma não individual" ${ }^{5}$.

O novo Código de Processo Civil traz o instituto da Repercussão Geral, mais especificamente, no seu artigo 1035, nos seguintes termos:

Art. 1.035. O Supremo Tribunal Federal, em decisão irrecorrível, não conhecerá do recurso extraordinário quando a questão constitucional nele versada não tiver repercussão geral, nos termos deste artigo.

$\S$ 1o Para efeito de repercussão geral, será considerada a existência ou não de questões relevantes do ponto de vista econômico, político, social ou jurídico que ultrapassem os interesses subjetivos do processo.

$\S 22^{\circ} \mathrm{O}$ recorrente deverá demonstrar a existência de repercussão geral para apreciação exclusiva pelo Supremo Tribunal Federal.

§ 3ํHaverá repercussão geral sempre que o recurso impugnar acórdão que:

I - contrarie súmula ou jurisprudência dominante do Supremo Tribunal Federal;

II - tenha sido proferido em julgamento de casos repetitivos;

III - tenha reconhecido a inconstitucionalidade de tratado ou de lei federal, nos termos do art. 97 da Constituição Federal. (BRASIL, 2015, p. 180).

Necessária, mas ainda não efetivada, é a caracterização desses elementos econômicos, políticos, sociais ou jurídicos que tornam a questão relevante e de repercussão geral, pois o legislador não os definiu. Nesta tentativa, Schlosser e Wickert assim os exemplificam:

A repercussão geral jurídica no sentido estrito existiria, por exemplo, quando estivesse em jogo o conceito ou a noção de um instituto básico do nosso direito, de modo que aquela decisão, se subsistisse, pudesse significar perigoso e relevante precedente, como a de direito adquirido. Relevância social haveria, numa ação em que se discutissem problemas relativos à escola, à moradia ou mesmo à legitimidade do Ministério Público para a propositura de certas ações. [...] Repercussão econômica haveria em ações que discutissem, por exemplo, o sistema financeiro da habitação ou a privatização de serviços públicos essenciais, como a telefonia, o saneamento básico, a infraestrutura, etc. Repercussão política haveria, quando, por exemplo, de uma causa pudesse emergir decisão capaz de influenciar relações com Estados estrangeiros ou organismos internacionais ${ }^{6}$.

${ }^{5}$ GOMES JÚNIOR, Luiz Manoel. A repercussão geral da questão constitucional no recurso extraordinário. Revista IOB de Direito Civil e Processo Civil. p. 148, 2005.

${ }^{6}$ SCHLOSSER, Lizelote Minéia. WICKERT, Lisiane Beatriz. A inserção e a regulamentação da repercussão geral como pressuposto de admissibilidade do recurso extraordinário. Revista de Processo, v. 33 , n. 161 , p. $123,2008$. 
No mesmo sentido, exemplifica Gomes Júnior:

a) reflexos econômicos: quando a decisão possuir potencial de criar um precedente outorgando um direito que pode ser reivindicado por um número considerável de pessoas (alteração nos critérios para se considerar a correção monetária dos salários de determinada categoria, p. ex.).

b) quando presente relevante interesse social: que tem uma vinculação ao conceito de interesse público, em seu sentido lato, ligado a uma noção de bem comum.

c) reflexos políticos: na hipótese de decisão que altere a política econômica ou alguma diretriz governamental de qualquer das esferas de governo (Municipal, Estadual ou Federal).

d) reflexos sociais: existirão quando a decisão deferir um direito ou indeferilo e essa mesma decisão vir a alterar a situação fática de várias pessoas. Nas ações coletivas, a regra é que sempre, em princípio, haverá repercussão geral a justificar o acesso ao STF, considerando a amplitude da decisão, claro, se a questão possuir natureza constitucional.

e) reflexos jurídicos: este é um requisito relevante, sob vários aspectos.

Será relevante a matéria deduzida no recurso extraordinário todas as vezes que for contrária ao que já decidido pelo STF ou estiver em desacordo com a jurisprudência dominante ou sumulada. Se o papel do STF é uniformizar a interpretação da $\mathrm{CF}$, decisões contrárias ao seu entendimento não podem ser mantidas?.

Deve ser também, considerado juridicamente relevante, com repercussão, quando a interpretação adotada pela decisão recorrida for aberrante ou absurda, por exemplo, quando evidentemente contrária ao texto constitucional.

Desta feita, não existindo uma definição específica, ou até mesmo um rol taxativo, das questões relevantes sob o ponto de vista econômico, político, jurídico ou social, caberá ao STF, por ser competência exclusiva, analisar tais questões, decidindo sobre a existência ou não de Repercussão Geral.

Para Araújo (2007), trata-se de aspecto subjetivo da questão constitucional com Repercussão Geral, "que deverá ser demonstrado pelo recorrente, cuja interpretação e conclusão acerca de sua presença são tarefas do STF, que, por meio de decisão fundamentada, reconhecerá ou afastará o requisito" ${ }^{8}$.

\footnotetext{
7 GOMES JÚNIOR, Luiz Manoel. A repercussão geral da questão constitucional no recurso extraordinário. Revista IOB de Direito Civil e Processo Civil, São Paulo, p. 148-149, 2005.

8 ARAÚJO, José Henrique Mouta. A eficácia da decisão envolvendo a repercussão geral e os novos poderes dos relatores e dos tribunais locais. Revista de Processo, São Paulo, v. 32, n. 152, p. 185$186,2007$.
} 
Trata-se de um poder discricionário atribuído ao STF, quando decidir sobre a existência ou não de Repercussão Geral, pois mesmo que a regra legislativa utilize termos vagos ou conceitos indeterminados, há parâmetros e valores que se impõem ao julgador de maneira cogente. O que se exige do aplicador é uma obra de interpretação que procure traduzir o sentido da vontade da lei diante das particularidades do caso concreto. Jamais estará ele livre para optar por uma deliberação que seja indiferente aos parâmetros e valores proclamados pela norma.

No mesmo sentido, afirmam Marinoni e Mitidiero:

Os conceitos jurídicos indeterminados são compostos de um núcleo conceitual (certeza do que é ou não é) e por um ralo conceitual (dúvida do que pode ser). No que concerne especificamente à repercussão geral, a dúvida inerente à caracterização desse halo de modo nenhum pode ser dissipada partindo-se tão somente de determinado ponto de vista individual; não há, em outras palavras, discricionariedade no preenchimento desse conceito. Há de se empreender um esforço de objetivação nessa tarefa. E, uma vez caracterizada a relevância e a transcendência da controvérsia, o Supremo Tribunal Federal encontra-se obrigado a conhecer do recurso extraordinário. Não há, aí, espaço para livre apreciação e escolha entre duas alternativas igualmente atendíveis. Não há de se cogitar aí, igualmente, discricionariedade no recebimento do recurso extraordinário. Configurada a repercussão geral, tem o Supremo de admitir o recurso e apreciá-lo no mérito?

Também se pode observar que os parágrafos do Artigo 1035 do Novo Código de processo Civil, apontaram situações em que a Repercussão Geral encontra-se categoricamente assentada:

$\S$ 1ํ Para efeito de repercussão geral, será considerada a existência ou não de questões relevantes do ponto de vista econômico, político, social ou jurídico que ultrapassem os interesses subjetivos do processo.

Art. 1035: [...]

$\S 2$ O $\mathrm{O}$ recorrente deverá demonstrar a existência de repercussão geral para apreciação exclusiva pelo Supremo Tribunal Federal.

$\S 3$ ํoverá repercussão geral sempre que o recurso impugnar acórdão que: I - contrarie súmula ou jurisprudência dominante do Supremo Tribunal Federal;

${ }^{9}$ MARINONI, Luiz Guilherme e MITIDIERO, Daniel. Repercussão geral no recurso extraordinário. 2 ed. São Paulo: Editora Revista dos Tribunais, 2008. p. 34. 
II - tenha sido proferido em julgamento de casos repetitivos;

III - tenha reconhecido a inconstitucionalidade de tratado ou de lei federal, nos termos do art. 97 da Constituição Federal.

Para Gomes Júnior, "a definição destas situações revela o aspecto objetivo da questão constitucional com Repercussão Geral" ${ }^{10}$.

A súmula, in casu, não precisa ser a vinculante, mas apenas a que retrate jurisprudência assentada, pois, mesmo sem súmula, a repercussão geral estará configurada em qualquer julgamento que afronte "jurisprudência dominante" do STF. Segundo Theodoro Júnior, por jurisprudência dominante, "deve-se ter a que resulta de posição pacífica, seja porque não há acórdãos divergentes, seja porque as eventuais divergências já tenham se pacificado no seio do STF" ${ }^{11}$.

Trata-se de presunção legal da existência de repercussão geral, pois sempre que a decisão recorrida for contrária à súmula ou jurisprudência do STF, haverá Repercussão Geral, que pode ser caracterizada sob o ponto de vista jurídico, uma vez que o dispositivo acima, segundo Araújo, "[...] objetiva servir de estímulo ao atendimento dos pronunciamentos da Corte Máxima" ${ }^{12}$.

Por mais vaga que possa ser a exigência do requisito da repercussão geral no juízo de admissibilidade do recurso extraordinário, nunca estará o STF livre para rejeitar arbitrariamente um recurso sobre a lacônica e imotivada alegação de ausência de tal requisito. Sempre terá de proceder ao esforço dialético de demonstrar, analiticamente, como se chegou ao juízo determinante da falta de repercussão geral, submetendo o caso concreto às exigências da razoabilidade. Reitera-se, por fim, que o legislador, mesmo não definindo categoricamente o que seria entendido como Repercussão Geral, apontou taxativamente situações, nos parágrafos do Artigo 1035 do NCPC, em que o requisito sempre estará presente, de modo a cumprir uma de suas finalidades: fazer com que o STF decida uma única vez cada questão constitucional, não se pronunciando em outros processos com idêntica matéria.

A seguir, apontam-se as diferenças e similitudes entre a Repercussão Geral e a Arguição de Relevância, para depois analisar o procedimento de exame do requisito da Repercussão Geral.

\footnotetext{
${ }^{10}$ GOMES JÚNIOR, Luiz Manoel. A repercussão geral da questão constitucional no recurso extraordinário. Revista IOB de Direito Civil e Processo Civil, p. 186, 2005.

${ }^{11}$ THEODORO JÚNIOR, Humberto. Repercussão Geral no Recurso Extraordinário (Lei no 11.418) e Súmula Vinculante do Supremo Tribunal Federal (Lei ${ }^{\circ}$ 11.417). Revista IOB de Direito Civil e Processo Civil, p. 105-106, 2006.

${ }^{12}$ ARAÚJO, José Henrique Mouta. A eficácia da decisão envolvendo a repercussão geral e os novos poderes dos relatores e dos tribunais locais. Revista de Processo, p. 187, 2007.
} 


\section{A REPERCUSSÃO GERAL E AARGUIÇÃO DE RELEVÂNCIA}

A condição de Repercussão Geral exigida para o Recurso Extraordinário e trazida pelo novo Código de Processo Civil, é diferente do instituto da Arguição de Relevância que vigorou de 1975 a 1988 no ordenamento jurídico brasileiro.

No dizer de Marinoni e Mitidiero:

Nada obstante tenham a mesma função de "filttragem recursal", a arguição de relevância de outrora e a repercussão geral não se confundem. A começar pelo desiderato: enquanto a arguição de relevância funcionava como um instituto que visava a possibilitar o conhecimento deste ou daquele recurso extraordinário a priori incabível, funcionando como um instituto com característica central inclusiva, a repercussão geral visa a excluir do conhecimento do Supremo Tribunal Federal controvérsias que assim não se caracterizem. [...] Os próprios conceitos de repercussão geral e arguição de relevância não se confundem. Enquanto este está focado fundamentalmente no conceito de "relevância", aquele exige, para além da relevância da controvérsia constitucional, a transcendência da questão debatida. Quanto ao formalismo processual, os institutos também não guardam maiores semelhanças: a arguição de relevância era apreciada em sessão secreta, dispensando fundamentação; a análise da repercussão geral, ao contrário, tem evidentemente de ser examinada em sessão pública, com julgamento motivado (art. 93, IX, da CF) ${ }^{13}$.

São institutos diferentes, pois sendo a Repercussão Geral uma "arguição com sinal trocado" 14 , a primeira objetiva a exclusão da apreciação do STF daquelas situações que não transcendam os interesses subjetivos da causa, enquanto que a arguição de relevância objetivava incluir à apreciação do STF as questões que demonstrassem "[...] a preponderância do interesse público, bem como [que] o reflexo da solução dada ao problema extravasava o exclusivo interesse das partes"15.

No entanto, Mancuso ${ }^{14}$ aponta semelhanças entre os referidos institutos: Em contraponto, impende reconhecer que entre a atual repercussão geral e a

${ }^{13}$ MARINONI, Luiz Guilherme e MITIDIERO, Daniel. Repercussão geral no recurso extraordinário. 2 ed. São Paulo: Editora Revista dos Tribunais, p. 30-31, 2008.

${ }^{14}$ MANCUSO, Rodolfo de Camargo. Recurso extraordinário e recurso especial. 10. ed. rev., ampl. e atual. de acordo com as leis 11.417 e 11.418/2006 e a emenda regimental STF21/2007. São Paulo: Revista dos Tribunais, 2007. p. 202.

${ }^{15}$ BARBOSA, Rafael Vinheiro Monteiro. Reflexos da repercussão geral no sistema de interposição conjunta do recurso extraordinário e do recurso especial e a sugestão para o problema. Revista de Processo, São Paulo, p. 167-168, 2008.

Revista do Direito Público, Londrina, v.11, n.1, p.163-182, jan./abr.2016 | DOI: 10.5433/1980-511X.2016v11n1p163 
antiga arguição de relevância existe um núcleo comum: por um lado, ambas configuram elementos de contenção do volume excessivo de causas dirigidas ao STF, e, de outro lado, na arguição de relevância a avaliação positiva não implicava, necessariamente, a subsequente admissibilidade do RE, que ficava ainda a depender do atendimento dos demais requisitos (EC 1/69, art. 119, III e alíneas); pois também a avaliação positiva sobre a repercussão geral (basta que quatro Ministros a atestem) não significa, necessariamente, que o RE vá ser conhecido, mas na verdade ela opera como um salvo-conduto para o sequencial exame dos fundamentos indicados nas alíneas do art. 102, III, da CF408.

Assim, "considerando-se as diferenças acima expostas, tanto a Repercussão Geral quanto a antiga Arguição de Relevância se assemelham no tocante a sua função de filtro recursal" ${ }^{16}$, ressaltando-se que apesar de não ser o retorno da Arguição de Relevância, a atual condição de Repercussão Geral, analisada pelo STF, “[...] veio com o intuito de aperfeiçoar o funcionamento e evitar que, num futuro próximo, seja inviabilizado o funcionamento deste Tribunal" ${ }^{17}$.

\section{PRINCIPAIS ALTERAÇÕES DO INSTITUTO DA REPERCUSSÃO GERAL TRAZIDAS PELO NOVO CPC}

A repercussão geral do recurso extraordinário é sistemática de racionalização de julgamento de demandas repetitivas, incorporada ao ordenamento nacional como solução para combater o elevado acervo de processos em tramitação no país, especialmente de recursos extraordinários. Esse método de julgamento implica atuação compartilhada entre o Supremo Tribunal Federal e os demais juízos brasileiros, na medida em que estes replicam a jurisprudência firmada por aquele, por meio da não admissibilidade, da declaração de prejuízo e da retratação, aplicadas a demandas que tratam de controvérsias análogas às de processos-paradigmas. $\mathrm{O}$ instituto foi inserido no artigo 102, $\S 3^{\circ}$, da Constituição Federal, e regulamentado inicialmente pela Lei

\footnotetext{
${ }^{16}$ ALVES E SILVA, Ticiano. Apreciação pelo juízo a quo da existência de alegação de repercussão geral. Revista de Processo, São Paulo, p. 141, 2008.

${ }^{17}$ SCHLOSSER, Lizelote Minéia. WICKERT, Lisiane Beatriz. A inserção e a regulamentação da repercussão geral como pressuposto de admissibilidade do recurso extraordinário. Revista de Processo, São Paulo, p. 124, 2008.
} 
11.418/2007, que acrescentou os artigos 543-A e 543-B ao atual Código de Processo Civil, e também pela Emenda 21 ao Regimento Interno do STF. Essa última, publicada em 3 de maio de 2007, definiu o marco temporal do início de aplicação da repercussão geral.

A racionalização do julgamento de recursos extraordinários, por reduzir a quantidade de processos apreciados pelo STF, viabiliza a correção de uma série de equívocos habituais em nossa prática judicial, como a existência de decisões divergentes para casos idênticos, o desenvolvimento de jurisprudência excessivamente defensiva e o comprometimento da razoável duração do processo. Com efeito, a repercussão geral, ao privilegiar a análise de temas constitucionais, em vez de processos subjetivos, desobstrui a agenda do STF, o que favorece a qualidade dos julgamentos, a celeridade e a uniformidade jurisprudencial em todo território nacional. O instituto, portanto, é dotado de muitos atributos positivos, desde que suas potencialidades sejam devidamente exploradas.

Nessa conjuntura, o novo Código de Processo Civil, que entrará em vigor em março de 2016, modifica, de forma substancial, a sistemática da repercussão geral e impõe novos desafios ao Supremo Tribunal Federal enquanto principal gestor do instituto. Há pelo menos quatro grandes transformações que decorrem da novel regulamentação prevista no artigo 1.029 e seguintes do novo CPC, todas com escopo de aperfeiçoar a racionalização do julgamento de demandas repetitivas:

I) cabimento de impugnação contra as decisões das instâncias de origem que aplicam a sistemática da repercussão geral;

II) estabelecimento de prazo para que o STF julgue os processosparadigmas da repercussão geral; e

III) possibilidade de desconsideração de vício formal de recurso tempestivo.

\subsection{O cabimento de impugnação contra decisões das instancias de origem que aplicam a repercussão geral}

No que diz respeito às impugnações contra decisões das instâncias de origem que aplicam a sistemática da repercussão geral, o Supremo Tribunal Federal decidiu, em 2009, não caber agravo de instrumento nem reclamação. Partiu-se do pressuposto de que admitir esses meios impugnativos significaria confrontar a lógica do sistema e restabelecer o modelo de análise 
casuística. Contudo, essas louváveis orientações, que permitiram o sucesso da repercussão geral em sua primeira fase, são agora postas em xeque pelo novo CPC, que dispõe expressamente sobre o cabimento de reclamação para garantir a observância de precedente proferido no julgamento de casos repetitivos (artigo 988, IV), além de prever o agravo em recurso extraordinário como recurso hábil contra a não admissibilidade ou a declaração de prejuízo em demandas múltiplas (artigo 1.042).

Em consequência dessas disposições, acredita-se que a interposição de agravo será uma etapa constante na sistemática da repercussão geral, que terá lugar na grande maioria dos casos em que as instâncias de origem declararem o prejuízo de recurso extraordinário repetitivo ou assentarem sua inadmissibilidade decorrente da rejeição de repercussão geral. Igualmente, pensa-se que a reclamação será frequentemente manejada como meio de insurgência, quando as partes não concordarem com as decisões judiciais da origem e invocarem suposto descumprimento de precedente proferido no julgamento de demandas repetitivas. Em sede de reclamação, há ainda a agravante de elas poderem ser propostas independentemente do grau de tramitação do processo principal, ou seja, atos de juízes de primeiro grau são passíveis de questionamento direto no STF, ao fundamento de aplicação indevida de tese da repercussão geral (artigo 988, IV, § $4^{\circ}$, do novo CPC).

As mudanças atribuem a função de Corte de revisão ao STF, na contramão do perfil de Corte constitucional que se vinha desenhando. Ademais, a abertura dessas vias processuais pode causar o colapso da repercussão geral, por isso é preciso que o Supremo Tribunal Federal esteja atento ao fenômeno e se prepare para gerenciar o elevado número de processos que lhe será destinado.

\subsection{O estabelecimento de prazo para que o STF julgue os processos paradigmas da repercussão geral}

O estabelecimento de prazo para julgamento de mérito dos temasparadigmas, o NCPC dispõe que o recurso afetado à sistemática da repercussão geral deve ser apreciado no prazo de um ano (artigo 1.035, $\S 9^{\circ}$, e artigo $1.037, \S 4^{\circ}$ ), sob pena de cessarem-se os efeitos da suspensão de processos nas instâncias de origem. ${ }^{18} \mathrm{O}$ novo Código também determina que

\footnotetext{
${ }^{18}$ De acordo com o novo CPC, transcorrido um ano desde o reconhecimento da repercussão geral sem que o mérito do recurso-paradigma seja julgado, os processos sobrestados nas instâncias de origem retomam seu curso normal (artigo 1.035, $\$ 10$, e $1.037, \S 5^{\circ}$ ), salvo se houver nova afetação da mesma matéria por outro relator $\left(1.037, \S 6^{\circ}\right)$.
}

Revista do Direito Público, Londrina, v.11, n.1, p.163-182, jan./abr.2016 | DOI: 10.5433/1980-511X.2016v11n1p163 
os feitos com repercussão geral reconhecida terão prioridade na tramitação sobre os demais casos, ressalvados os que envolvam réu preso e os pedidos de habeas corpus.

É preciso reconhecer que a demora no julgamento dos temas com repercussão geral reconhecida causa prejuízos expressivos. Isso porque, embora as demandas sobrestadas nos juízos de origem não sejam contadas nas estatísticas do STF, elas aguardam indefinidamente pelo julgamento de mérito do processo-paradigma, sem o qual não podem ser examinadas. Assim, infunde-se uma falsa imagem de eficiência, com base em dados que atestam a diminuição do acervo na Suprema Corte, enquanto a realidade é que o sobrestamento indefinido de feitos nos juízos de origem provoca tão somente transferência geográfica de processos, que continuam a não respeitar o princípio da razoável duração.

Nesse cenário, registre-se que as normas atualmente em vigor, que não definem procedimentos e prazos criteriosos para o julgamento de mérito de processos-paradigmas, possibilitaram a instalação de imbróglio crítico: há temas cuja repercussão geral foi admitida em 2007 e os méritos respectivos não foram apreciados até a presente data - cerca de oito anos após. O estabelecimento de prazo para julgamento de temas com repercussão geral reconhecida coíbe essa situação e conduz a uma gestão que dispense tratamento preferencial aos recursos-paradigmas, porquanto se considera que o novo CPC produz grande avanço nesse ponto.

\subsection{A possibilidade de desconsideração de vício formal de recurso tempestivo}

Por fim, a possibilidade de superação de vício formal de recurso tempestivo trazida pelo artigo $1.029, \S 3^{\circ}$. Senão, vejamos:

Art. 1.029. O recurso extraordinário e o recurso especial, nos casos previstos na Constituição Federal, serão interpostos perante o presidente ou o vicepresidente do tribunal recorrido, em petições distintas que conterão:

I - a exposição do fato e do direito;

II - a demonstração do cabimento do recurso interposto;

III - as razões do pedido de reforma ou de invalidação da decisão recorrida. $[\ldots]$ 
§ 3응 O Supremo Tribunal Federal ou o Superior Tribunal de Justiça poderá desconsiderar vício formal de recurso tempestivo ou determinar sua correção, desde que não o repute grave.

Tal instituto revela a primazia atribuída à questão material pelo novo diploma, uma vez que se autoriza a aplicação do direito material mesmo nos feitos em que não há pressuposto recursal. O único pressuposto não flexibilizado foi a tempestividade, pois há outros valores de direito material que se revelam após a preclusão, como a segurança jurídica. Assim, considerando que o recurso interposto a destempo não impede a formação de coisa julgada, o legislador optou por manter a estabilidade da relação jurídica já consolidada, razão pela qual não se deve aplicar a sistemática da repercussão geral. Nos demais casos, itens de ordem processual podem ser flexibilizados para que se aplique o direito material incidente.

Trata-se de medida tendente a favorecer a uniformização de jurisprudência, evitando que jurisdicionados que se enquadram no mesmo status jurídico recebam decisões diversas, em virtude da eventual falta de pressupostos recursais.

\section{A Lei 13.256/2016}

O novo Código de Processo Civil entra em vigor no dia 18 de março de 2016. Duas preocupações centrais podem ser facilmente identificadas no novo Código - racionalizar e aperfeiçoar a prestação jurisdicional.

Foram criados mecanismos para tornar mais ágil o julgamento e o desfecho dos processos, como os incidentes de resolução de demandas repetitivas, a assunção de competência, os julgamentos liminares, aprimoramento das tutelas de urgência, dos recursos repetitivos, etc.

E, nessa mesma linha, o novo CPC tenta valorizar o respeito à jurisprudência já firmada no âmbito dos Tribunais. Os juízes devem observar, para proferir uma sentença, se já existe precedente sobre o assunto, nos Tribunais Superiores ou no seu Tribunal. Isso, para evitar que o julgamento contrário à jurisprudência já consolidada gere recursos desnecessários, que colocam em risco, além do tempo da prestação jurisdicional, a própria segurança jurídica.

Com tantos pontos positivos pode parecer estranho que o novo $\mathrm{CPC}$, 
antes mesmo da sua entrada em vigor, seja alterado, como ocorreu com a edição da lei 13.256, em 5/2/16.

Em síntese, a lei 13.256/16 resgata algumas normas que seriam revogadas com a entrada em vigor do novo $\mathrm{CPC}$, na tentativa de manter a sistemática existente hoje, além de alterar e revogar outras. Vejamos as principais.

O novo CPC acabava com a chamada dupla admissibilidade dos recursos para os Tribunais Superiores - todo e qualquer recurso interposto subiria dos Tribunais Estaduais e Regionais Federais diretamente para o STF e o STJ. Alvo de muitas críticas, por poder levar a um aumento de processos nas já movimentadas Cortes Superiores, a alteração parece se justificar para atender ao reclamo do Supremo Tribunal Federal e do Superior Tribunal de Justiça, que pretendem, inclusive com a aplicação dos novos mecanismos previstos na legislação, reduzir o volume de processos em tramitação em nome do julgamento mais detido de teses e questões relevantes.

Outrossim, houve o restabelecimento do chamado duplo juízo de admissibilidade dos recursos especiais e extraordinários (arts. 1.029 e seguintes, NCPC), a fim de manter-se o sistema atual em que os Tribunais previamente analisam o preenchimento dos requisitos antes da remessa dos respectivos recursos ao STJ ou STF.

\section{CONSIDERAÇÕES FINAIS}

A relevante modificação no Juízo de Admissibilidade do Recurso Extraordinário gerada pela inserção do requisito da Repercussão Geral no $\S 3^{\circ}$ do artigo 102 da Constituição da República Federativa do Brasil de 1988, por meio da Emenda Constitucional n. 45/2004, provocou a curiosidade quanto à configuração da nova condição exigida. Com a regulamentação sobre o requisito da Repercussão Geral, através da Lei n. 11.418/2006 e da Emenda Regimental n. 21 do Supremo Tribunal Federal, surgiram muitos questionamentos acerca dos elementos que configurariam o dito requisito, já que a própria lei não disponibilizou conceito claro e objetivo sobre o assunto.

Com o advento do Novo Código de Processo Civil, a disciplina da repercussão geral no novo Código de Processo Civil traz algumas melhorias, como a previsão de prazo para julgamento de mérito de temas-paradigmas 
e a possibilidade de superação de vícios formais do recurso tempestivo. Contudo, é preciso que o Supremo Tribunal Federal se prepare para administrar a quantidade de processos que lhe será dirigida em breve.

Os recursos são regidos por princípios específicos que orientam tanto o legislador, ao normatizá-los, quanto o julgador, ao apreciá-los. O Princípio do Devido Processo Legal é a base sobre a qual todos os demais se sustentam, garantindo o direito de acesso ao Poder Judiciário e o desenvolvimento processual de acordo com normas previamente estabelecidas. Completando-o, o Princípio da Razoável Duração do Processo visa garantir maior efetividade e menos morosidade no andamento e julgamento dos processos.

Da mesma forma que uma ação precisa preencher determinadas condições para o pronunciamento do mérito, também os recursos devem cumprir alguns pressupostos, denominados Requisitos de Admissibilidade. Eles dividem-se em Intrínsecos, relacionados à existência do direito de recorrer, e Extrínsecos, relativos ao exercício desse direito. Os primeiros correspondem ao cabimento do recurso, que significa ser o recurso interposto o adequado para impugnar o ato decisório; à legitimação para recorrer, segundo a qual existem determinadas pessoas qualificadas para a utilização dos recursos, cabendo a estas, unicamente, figurar como recorrentes; ao interesse processual que deve ser evidenciado, de modo que o recurso se mostre útil e necessário ao recorrente; e, ainda, à inexistência de fato impeditivo ou extintivo do direito, essencial para a prolação do juízo positivo de admissibilidade do recurso. Os pressupostos extrínsecos são: a tempestividade, devendo o recurso ser interposto no prazo estabelecido por lei; a regularidade formal, que exige que o recurso seja interposto por petição, contendo motivação e pedido de nova decisão; e o preparo, correspondendo ao pagamento prévio das despesas com o procedimento do recurso.

O Recurso Extraordinário é um recurso excepcional, destinado a corrigir afronta à Constituição, visando tutelar direito objetivo. Sua interposição é feita perante o órgão prolator da decisão recorrida que analisará o preenchimento dos Requisitos de Admissibilidade e, em caso positivo, o encaminhará ao Supremo Tribunal Federal para apreciação e julgamento do mérito.

Só será admitido o Recurso Extraordinário que se baseie em causa decidida, ou seja, em que tenha sido resolvida a lide, e desde que todas as 
demais vias recursais tenham sido esgotadas, não cabendo, desta forma, nenhum outro tipo de recurso. Tampouco não cabe ao Recurso Extraordinário ensejar a revisão de matéria de fato pelo STF, cuja tarefa é remetida às instâncias inferiores.

O Recurso Extraordinário deve-se fundar nas hipóteses do artigo 102, inciso III, da CRFB/88. Assim, nos casos de decisão contrária a dispositivo da Constituição, ou que declare a inconstitucionalidade de tratado ou lei federal, ou que julgue válido ato normativo local contestado em face da Constituição, ou, ainda, que julgue válida lei local em face de lei federal, nestes casos caberá Recurso Extraordinário ao STF.

Porém, o cerne desta pesquisa encontra-se no requisito de Repercussão Geral exigido para a admissibilidade do Recurso Extraordinário, que corresponde à existência de questões relevantes do ponto de vista econômico, político, social ou jurídico, que ultrapassem os interesses subjetivos da causa.

Sendo um requisito intrínseco de admissibilidade do Recurso Extraordinário, verificou-se que a Repercussão Geral tem a função de filtrar o excesso de recursos levados ao STF, que muitas vezes, apesar de alegarem controvérsia à Constituição, não transcendem aos interesses subjetivos das partes, o que acaba convertendo aquele tribunal em uma terceira ou quarta instância de julgamentos, atrapalhando o cumprimento de sua real função como garantidor da unidade e autoridade da Constituição.

A doutrina entende que o Supremo Tribunal Federal não age com discricionariedade quando determina o reconhecimento ou afastamento da Repercussão Geral, pois sua decisão deverá ser fundamentada de acordo com as próprias exigências da Constituição. A partir do momento que uma causa revela questão de Repercussão Geral, esta servirá como parâmetro para as de idêntica controvérsia.

Embora haja este entendimento, há que se pontuar que existe sim uma discricionariedade na decisão do STF quando reconhece ou afasta a Repercussão Geral, uma vez que não existem situações sobre os aspectos econômicos, políticos, sociais ou jurídicos, cabendo ao mencionado Tribunal analisar cada caso, decidindo pela existência ou não da Repercussão Geral. A discricionariedade não se trata de ampla e irrestrita liberdade para decidir se a questão é relevante ou não sob os aspectos citados, mas de uma 
liberdade limitada pela lei. Assim, mesmo limitada, ela permite ao Supremo Tribunal Federal certa flexibilidade ao enquadrar as situações como de Repercussão Geral ou não, que pode variar, até mesmo, de acordo com o momento político vivido pelo país, desde que por decisão devidamente fundamentada.

A análise da Repercussão Geral é de competência exclusiva do Supremo Tribunal Federal, cabendo ao órgão de origem da decisão recorrida apenas analisar a alegação de Repercussão Geral que deverá ser feita em preliminar das razões recursais. Sobre o reconhecimento e o afastamento da Repercussão Geral somente o STF poderá se manifestar.

A partir do problema elaborado para esta pesquisa, com base no que foi estudado e apresentado, conclui-se que há elementos teóricos e práticos que devem ser considerados para a configuração do requisito da Repercussão Geral para fins de interposição do Recurso Extraordinário, os quais encontram sua delimitação na legislação infraconstitucional, em razão do disposto no artigo 1029 e seguintes do Novo Código de Processo Civil.

A Repercussão Geral é Requisito de Admissibilidade a ser analisado e configurado de acordo com o que dispõe o NCPC, independentemente das hipóteses de cabimento em que se fundar o Recurso Extraordinário. Desta forma, não interfere no Juízo de Admissibilidade da Repercussão Geral se o Recurso Extraordinário impugna decisão que contrarie a Constituição, ou declare a inconstitucionalidade de tratado ou lei federal, ou julgue válida lei ou ato de governo local contestada em face da Constituição, ou, ainda, julgue válida lei local contestada em face de lei federal.

\section{REFERÊNCIAS}

ALVES E SILVA, Ticiano. Apreciação pelo juízo a quo da existência de alegação de repercussão geral. Revista de Processo, São Paulo: Revista dos Tribunais, v. 33, n. 161, p. 135-153, jul. 2008.

ARAÚJO, José Henrique Mouta. A eficácia da decisão envolvendo a repercussão geral e os novos poderes dos relatores e dos tribunais locais. Revista de Processo, São Paulo: Revista dos Tribunais, v. 32, n. 152, p. 164, out. 2007. 
BARBOSA, Rafael Vinheiro Monteiro. Reflexos da repercussão geral no sistema de interposição conjunta do recurso extraordinário e do recurso especial e a sugestão para o problema. Revista de Processo, São Paulo: Revista dos Tribunais, v. 33, n. 158, p. 163, abril. 2008.

BORGES, Marcos Afonso. O recurso extraordinário e a repercussão geral. Revista de Processo, São Paulo: Revista dos Tribunais, v. 33, n. 156, p. 36-44, fev. 2008.

BRASIL. Código de processo civil. Brasília, 2015. 191 p. Disponível em:< http:/www.planalto.gov.br/ccivil_03/_ato2015-2018/2015/lei/ 113105.htm>. Acesso em: 14 fev. 2016.

GOMES JÚNIOR, Luiz Manoel. Repercussão geral da questão constitucional no recurso extraordinário. Repertório IOB de Jurisprudência: civil, processual penal e comercial, n. 3, p. 148-149, 1. quinz. fev. 2005.

MANCUSO, Rodolfo de Camargo. Recurso extraordinário e recurso especial. 10. ed. rev., ampl. e atual. de acordo com as leis $11.417 \mathrm{e}$ 11.418/2006 e a emenda regimental STF21/2007. São Paulo: Revista dos Tribunais, 2007.

MARINONI, Luiz Guilherme. Manual do processo de conhecimento. 9. ed. rev., atual. e ampl. São Paulo: Revista dos Tribunais, 2010.

MARINONI, Luiz Guilherme e MITIDIERO, Daniel. Repercussão geral no recurso extraordinário. 2 ed. São Paulo: Revista dos Tribunais, 2008.

MONTENEGRO FILHO, Misael. Curso de direito processual civil: teoria geral dos recursos, recursos em espécie e processo de execução. 4. ed. São Paulo: Atlas, 2007.

\section{NERY JÚNIOR, Nelson. Princípios do processo civil na}

Constituição Federal. 8. ed. rev., ampl. e atual. São Paulo: Revista dos Tribunais, 2009. 
SCHLOSSER, Lizelote Minéia; WICKERT, Lisiane Beatriz. A inserção e a regulamentação da repercussão geral como pressuposto de admissibilidade do recurso extraordinário. Revista de Processo, São Paulo, v.33, n. 161, 2008. p. 15-134.

TAVARES, André Ramos. Curso de direito constitucional. 8. ed. rev. e atual. São Paulo: Saraiva, 2009.

THEODORO JÚNIOR, Humberto. Curso de direito processual civil: teoria geral do direito processual civil e processo de conhecimento. 44. ed. Rio de Janeiro: Forense, 2006.

Artigo recebido em: 13/11/2015 Aprovado para publicação em: 21/03/2016

Como citar: ESTEVES, João Luiz Martins. SANTANA, Lucas Ferreira. O Instituto da Repercussão Geral no Recurso Extraordinário e o Novo Código De Processo Civil. Revista do Direito Público. Londrina, v.11, n.1, p.163-182, jan/abr.2016. DOI: 10.5433/1980-511X.2016v11n1p163. ISSN: 1980-511X. 